\title{
Distribution of echinoids and palaeozoogeographic units of the Cenomanian-Santonian basins of the Caucasus and Mediterranean regions
}

\author{
Mamedalizade A.M. \\ Baku State University, Faculty of Geology, Zahid Halilov str. 23, AZ1148, Baku, Azerbaijan; (aladdin-mamedalizade@rambler.ru) \\ doi: $10.4154 / g c .2019 .04$
}

Article history:

Manuscript received May 20, 2018

Revised manuscript accepted October 31, 2018

Available online February 15, 2019

Keywords: Late Cretaceous, Echinoids,

palaeozoogeography, classification, Lesser

Caucasus

\begin{abstract}
Based on the palaeontological materials of the Cenomanian, Turonian, Coniacian and Santonian in the Caucasus, taxonomic composition, geographic distribution and migration routes of sea urchins are presented. Furthermore the possibility of identifying zoogeographic units in the Late Cretaceous basins of the Caucasus are discussed.
\end{abstract}

\section{INTRODUCTION}

The palaeozoogeographic zonation of ancient oceans and continents is one of the main methods of comparative palaeobiogeography. At the beginning of the last century, general scientific works of HAUG (1908-1911) were devoted to this study.

Patterns of the biogeographic distribution of palaeobasins of different geological ages along with the principles of palaeozoogeographical zonation have been highlighted in the works of, among others, MAKRIDIN \& KATZ, (1966), MAKRIDIN (1973, 1982, 1983), WESTERMANN (2000), CESSA \& WESTERMANN (2003), and MAMEDALIZADE (2011).

A description of the palaeontological materials of sea urchins of the Late Cretaceous of the Caucasus and the stratigraphic distribution of many species were widely covered in the works of MOSKVIN (1949), POSLAVSKAYA \& MOSKVIN (1959), RENGARTEN (1959), GAMBASHIDZE (1967), GONGADZE (1979), MOSKVIN (1986), KHALILOV \& MELIKOV (1988), MELIKOV (2002, 2005), MAMEDALIZADE (2005).

The Upper Cretaceous deposits of the Caucasus are characterized by a rich diversity of fossils, of which the class Echinoidea is well represented. The systematic composition and zoogeography of the sea urchins of the Late Cretaceous of this region have been relatively poorly studied. In this context, an attempt is made to highlight some issues concerning the distribution of Late Cretaceous sea urchins of Cenomanian, Turonian, Cogniacian and Santonian ages from the Caucasus on the basis of the collected specimens and published data in the literature.

\section{MATERIALS}

The basis of this study is the author's own collections from Upper Cretaceous sediments collected during numerous field expeditions in the Caucasus. In all, about 900 specimens of sea urchin skeletons belonging to the Echinoneoida, Diadematoida, Holasteroida, Cassiduloida, Spatangoida and Clypeasteroida were collected from a wide range of ages. In this study, the classification scheme proposed by SMITH \& KROH (2011) is followed.

\section{DISCUSSION}

In general, Cenomanian sea urchins of the Caucasus are not common. They are represented by few specimens as noted by POSLAVSKAYA \& MOSKVIN (1959).

In the Cenomanian stage, the sea urchins Holectypus exciscus DESOR, H. cenomanensis GUÉRANGER, Conulus laevis AGASSIZ, Nucleolites morrisi d'ORBIGNY, Catopygus columbaris (LAMARCK) and Holaster subglobosus (LESKE) (Fig. 1) existed in the marine basins of the Azerbaijanian part of the Lesser Caucasus. The literature concerning the geographical distribution of these species is very scarce. In the Cenomanian, the widest geographical area is shown by Holaster subglobosus, the remains of which were also observed in the Northern Caucasus and the Kopet-Dag Mountain Range in the border region between Turkmenistan and Iran POSLAVSKAYA \& MOSKVIN (1959). In addition to this species, Camerogalerus cylindrica LAMARCK also appears in Cenomanian deposits of the Northern Caucasus.

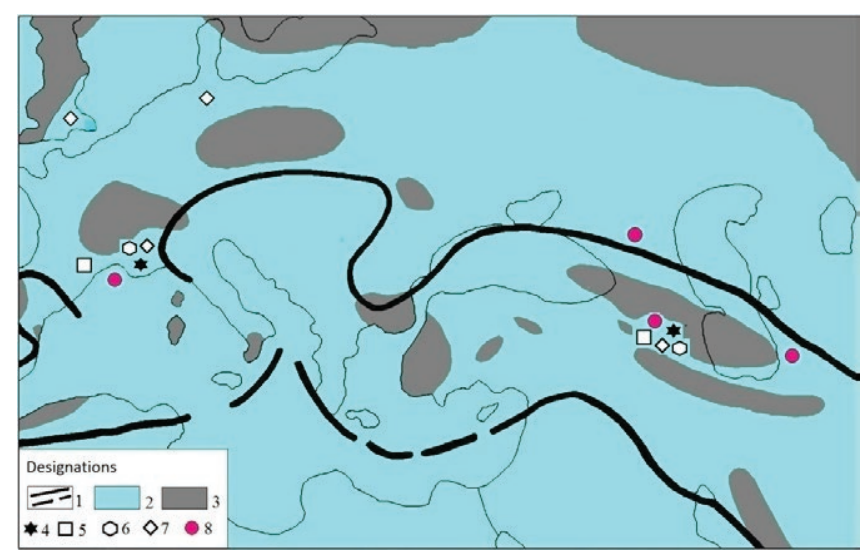

Figure 1. A geographical distribution of sea urchins of the Caucasus in the Cenomanian. Designations: (1) boundary of the Mediterranean Region; (2) sea; (3) land; echinoid genera: (4) Holectypus;(5) Conulus; (6) Nucleolites; (7) Catopygus; (8) Holaster. 
According to GONGADZE (1979), Cenomanian sea urchins of Georgia are represented by the species Discoides cf. subucula (KLEIN), Pyrina orbygniana (AGASSIZ), P. cf. laevis (AGASSIZ) and $P$. cf. tumida (GAUTHIER).

Cenomanian sea urchins of the Azerbaijanian part of the Lesser Caucasus, Georgia and the Northern Caucasus differ sharply from one another with respect to their species composition. Despite this, there is a general distribution of the species Holaster subglobosus in the Late Cenomanian in both the Lesser Caucasus and the Northern Caucasus regions.

By the end of the Cenomanian, Holectypus exciscus, $H$. cenomanensis, Nucleolites morrisi, Catopygus columbaris and Conulus laevis cease to exist in the area of the Lesser Caucasus (Azerbaijanian part). In the Turonian, Holaster subglobosus is replaced by H. planus MANTELL. The genus Conulus is represented by a new species composition consisting of $C$. rhotomagensis (SISMONDA), C. ellipticus (ZARECZNY), C. subconicus (d'ORBIGNY), C. vulgaris (LESKE), C. djanelidzei GONGADZE and C. subrotundus (MANTELL).

The Turonian sea urchins of the Lesser Caucadus, C. rhotomagensis, C. ellipticus, ${ }_{2}$ C. subconicus, existed in the Early Turonian marine basin. In the second half of the Turonian, together with Holaster planus, representatives of both Echinocorys (Echinocorys sphaericus (SCHLÜTER), E. gravesi DESOR, E. gibbus (LAMARCK) and Micraster (Micraster leskei d'ORBIGNY), are observed for the first time in this area.

In the Georgian part of the Caucasus (the Dzuril massif and the district of Kutaisi) the genus Pyrina ceases to exist at the end of the Cenomanian and Discoides cf. subucula (KLEIN) is replaced by Discoides minima AGASSIZ, Camerogalerus minimus AGASSIZ. Together with this species in the Turonian, Conulus vulgaris, C. subrotundus and Hemiaster nucleus DESOR (GONGADZE, 1979) also appear for the first time in the Dzuril Massif.

In the Northern Caucasus, during the transition from the Cenomanian to the Turonian, the species Camerogalerus cylindrica (LAMARCK) disappears, and Holaster subglobosus is replaced by $H$. planus. Along with these species, eight completely new species of sea urchins appear within the genera Conulus, Echinocorys, Infulaster and Micraster in the Turonian (POSLAVSKAYA \& MOSKVIN, 1959).

All sea urchin species appearing in the Turonian in the Caucasus (with the exception of Micraster subglobosus POSLAVSKAYA \& MOSKVIN) were first described from the Late Cretaceous of Western Europe.

In the Azerbaijanian part of the Lesser Caucasus, four echinoid species present in the Turonian belong to the genus Conulus. Among these, only Conulus subrotundus and C. subconicus have been recorded from the Upper Turonian deposits of Georgia (GONGADZE, 1979) and the Northern Caucasus (POSLAVSKAYA \& MOSKVIN, 1959).

Conulus subrotundus and C. subconicus were distributed more widely - ranging from the Anglo - Paris Basin to the KopetDag Mountains.

The species Conulus subrotundus, shifted its distribution in the second half of the Turonian from west to east in the direction of the Donbas, Crimea, Greater Caucasus, Mangystau Peninsula in western Kazakhstan, the Lesser Caucasus and the Kopet-Dag Mountain areas. It is also known from both the Lower and Upper Turonian deposits of England, France, Germany, Romania, Belgium and Poland (Fig. 3).

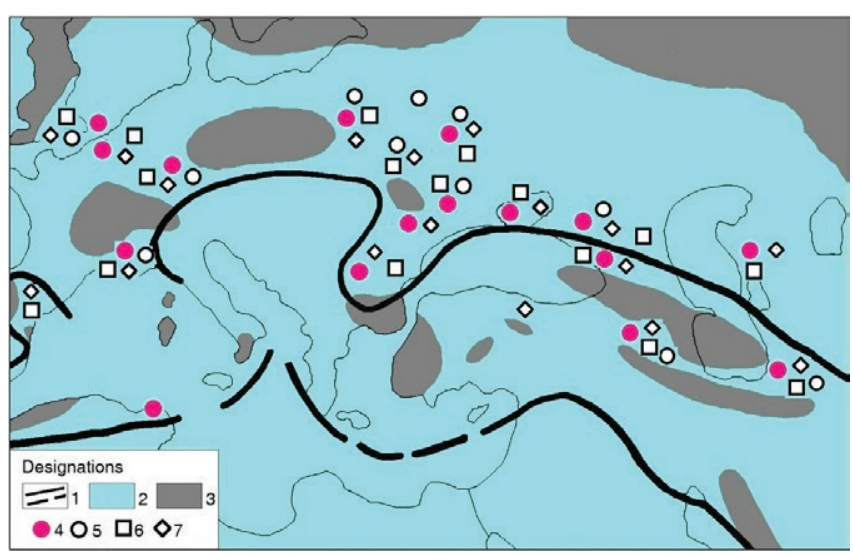

Figure 2. A geographical distribution of genera of sea urchins of the Caucasus in the Turonian. Designations: (1) boundary of the Mediterranean Region; (2) sea; (3) land; echinoid genera: (4) Conulus; (5) Holaster; (6) Echinocorys; (7) Micraster.

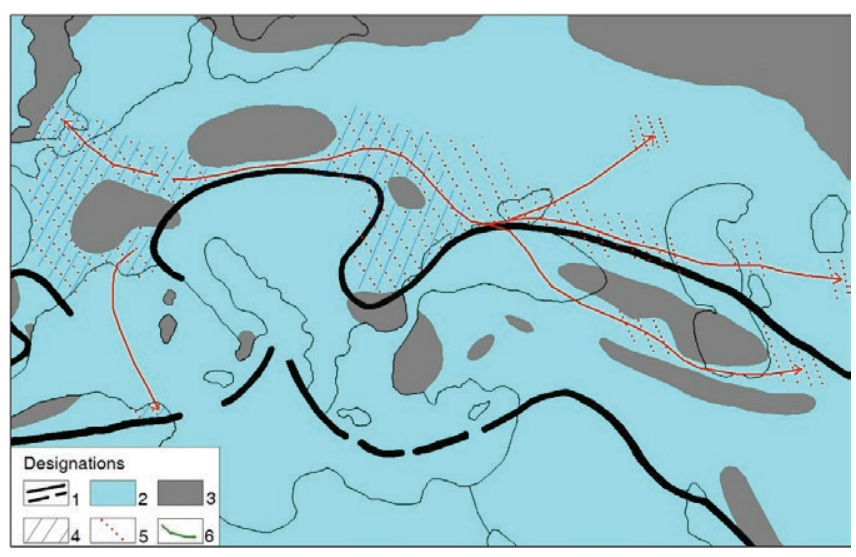

Figure 3. The range of Conulus subrotundus MANTELL in the Turonian. Designations: (1) boundary of the Mediterranean Region; (2) sea; (3) land; (4) Early Turonian; (5) Late Turonian; (6) dispersal direction.

Holaster planus, which has a wide geographical extent from Western Europe to the Kopet-Dag Mountains, appeared in the second half of the Turonian in the Lesser Caucasus and Northern Caucasus. It is a zonal species for the Late Turonian in the Caucasus, the Transcaspian area (eastern Kazakistan and Turkmenistan), and in Europe.

Echinocorys sphaericus, which is of great stratigraphic importance for the Upper Turonian deposits of the Donbas, Crimea, Caucasus, and the Transcaspian, also had a wide geographical distribution. It was first recorded in Lower Turonian age deposits of England, France, Belgium, Poland, and migrated in the second half of the Turonian period towards the Carpathians, Crimea, and then onwards to the Northern Caucasus, the Mangystau Peninsula and the Lesser Caucasus as well as the Kopet-Dag Mountains.

The Turonian sea urchins of the Lesser Caucasus are similar in species composition to the sea urchins of Western Europe. Their distribution indicates that, there was a broad Middle European palaeozoogeographic region in both the Cenomanian and the Turonian.

The composition of the sea urchins of the Coniacian of the Caucasus differs from that of the Cenomanian and the Turonian with respect to their generic and species composition. Thus, the genera Conulus, Echinocorys and Micraster, which existed in the basins of the Lesser Caucasus in the Turonian, are represented in the Coniacian by several new species. In addition, new genera of 
Cardiotaxis and Isomicraster appear for the first time. In this stage in the marine basins of the Lesser Caucasus, the number of species of the genus Conulus decreases from four to three. Despite this fact, two new species, Conulus ovulum LAMARCK and $C$. raulini COTTEAU occur along with $C$. subconicus. With the appearance of Micraster coranguinum KLEIN in the second half of the Coniacian, the number of common species is eleven (Fig. 4).

In comparison with the Azerbaijan part of the Lesser Caucasus, in the Dzirul Massif of Georgia and Northern Caucasus, there was a significant reduction in sea urchin abundance during the transition from the Turonian to the Coniacian. In Georgia, only Conulus subconicus passes from the Turonian into the Coniacian (GONGADZE, 1979), together with C. subconicus and Echinocorys gravesi DESOR (POSLAVSKAYA \& MOSKVIN, 1959) in the Northern Caucasus. In addition, two new species also appear in the Northern Caucasus; Echinocorys vulgaris BREYNIUS and Micraster coranguinum.

The analysis of the sea urchin assemblages of the Caucasus and the Donetsk Basin indicate that the connection between the Boreal Sea and Neotethys which existed in the Cenomanian and Turonian continued to remain open throughout the Coniacian. At that time, common species from the Caucasus migrated from northern regions to the southern edges of the European palaeozoogeographic region (Caucasus and Transcaspian) through to the Crimea Peninsula. An example is the common presence of species of the Donetsk Basin (SAVCHINSKAYA, 1974, 1982) with areas of the Donbas, Caucasus, and the Transcaspian regions including Conulus subconicus, E. gravesi, E. vulgaris, the Early Coniacian Micraster cortestudinarium GOLDFUUS and Late Coniacian M. coranguinum.

A connection that existed in the Coniacian, between the Boreal Sea and Neotethys, was previously reported by TSAGARELI (1954), NAIDIN (1964) and ALI-ZADE (1972). These researchers believed that there was no climatic barrier between the Boreal Sea and Neotethys, as many species of belemnites and inoceramid bivalves migrated from the north to the south and settled in the areas of both the Greater and Lesser Caucasus.

Sea urchins of Western European appearance (especially the Central European ones) observed in the Coniacian sediments of the Caucasus once again indicate the lack of a climatic barrier between the Boreal Sea and Neotethys and that many species could freely migrate from the north to south and from south to east.

In deposits of Santonian age of the Lesser Caucasus, sea urchins are represented by twelve species belonging to five genera (Fig. 5). Coniacian and Santonian sea urchins are similar to one other (with $\sim 60 \%$ of the total species). The Coniacian genera $\mathrm{Co}$ nulus, Cardiotaxis, Echinocorys, Micraster and Isomicraster are present here along with a number of the new species. These are Conulus albogalerus KLEIN, C. oblongus d'ORBIGNY, Cardiotaxis mundus RENGARTEN, Echinocorys scutatus LESKE, Micraster turonensis BAYLE, M. rostratus (MANTELL) and Isomicrster senonensis (LAMBERT). In addition, there are also three species that pass from the Coniacian to the Santonian including Conulus raulini COTTEAU Cardiotaxis maximus (SCHLÜTER) and Micraster coranguinum.

The analysis of both field observations and literature data shows that in the Santonian marine basins of the Lesser Caucasus and Northern Caucasus, there were only two common species with Micraster coranguinum and M. rostratus. Despite this, the sea urchin fauna of Santonian age of the Caucasus had a wide geographic distribution ranging from Western Europe to the eastern margin of the Kopet-Dag Mountains. Conulus subconicus,
Echinocorys vulgaryis, Micraster cortestudinarium (GOLDFUUS) and $M$. coranguinum also show a wide geographical distribution. In the Coniacian and Santonian, these species existed in the marine basins of Western Europe, Northern Africa (Algeria, Tunisia) and along the southern edge of the European palaeozoogeographic region, while Conulus albogalerus was able to

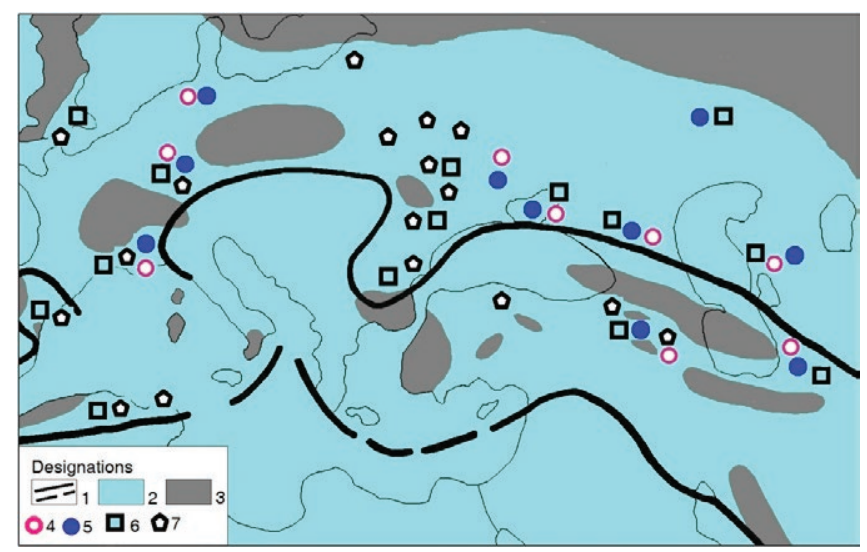

Figure 4. A geographical distribution of sea urchin of the Caucasus in the Cogniacian. Designations: (1) boundary of the Mediterranean Region; (2) sea; (3) land; echinoid range: (4) Conulus; (5) Cardiotaxis, (6) Echinocorys; (7) Micraster.

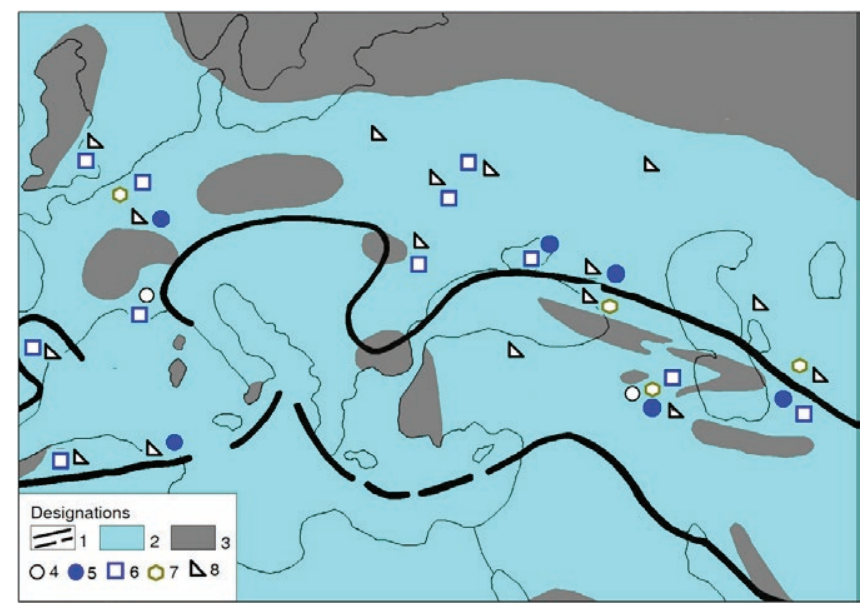

Figure 5. A geographical distribution of sea urchin of the Caucasus in the Santonian. Designations: (1) boundary of the Mediterranean Region; (2) sea; (3) land; echinoid genera: (4) Conulus; (5) Cardiotaxis; (6) Echinocorys; (7) Isomicraster; (8) Micraster.

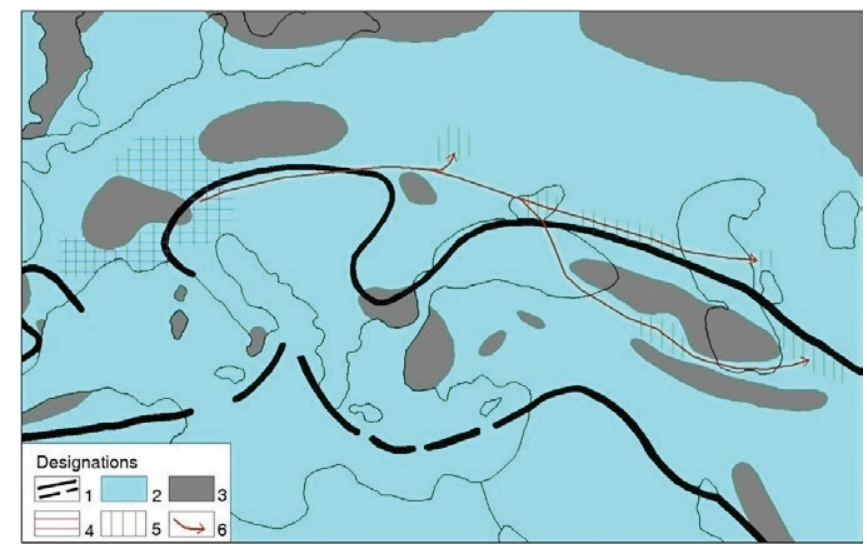

Figure 6. The range of Echinocorys vulgaris BREYNIUS the Coniacian and Santonian. Designations: (1) boundary of the Mediterranean Region; (2) sea; (3) land; (4) Coniacian; (5) Santonian; (6) dispersal direction. 
migrate to Northern India. Echinocorys vulgaris first appeared in Western Europe in the Coniacian, and in the Santonian it migrated eastward to the Donetsk basin, the Crimea Peninsula, the Lesser Caucasus, and the Kopet-Dag Mountains (Fig. 6). Micraster rostratus and Paronaster cupuliformis AIRAGHI also had a wide geographical distribution from Western Europe to the eastern edge of Kopet-Dag Mountains. Paronaster cupuliformis first appears in the early Campanian in the Azerbaijanian part of the Lesser Caucasus.

In Georgia (according to GONGADZE, 1979) during the transition from the Coniacian to the Santonian, of the two Coniacian species, Conulus vulgaris goes extinct while, $C$. djanelidze passes into the Santonian. Along with representatives of the genus Conulus, a new genus Micraster appears, with two species (Micraster cf. coranguinum and $M$. cf. rostratus) present for the first time. Micraster coranguinum appeared in the Lesser Caucasus and Northern Caucasus even earlier in the second half of the Coniacian.

The Santonian sea urchins of the Northern Caucasus, are relatively diverse compared to those of the earlier stages (POSLAVSKAYA \& MOSKVIN, 1959). Among the Coniacian species, only Micraster coranguinum passes into the Santonian. Echinocorys gravesi is replaced by Echinocorys turritus LAMBERT, and the genus Micraster is represented in the Santonian by Micraster heberti LACVIVIER and M. rostratus. Together with these species, in the second half of the stage, new species occur in the Northern Caucasus, namely Offaster pomeli MUNIER-CHALMAS, Paronaster cupuliformis AIRAGHI and Ornithaster sokolovi MOSKVIN \& POSLAVSKAYA (POSLAVSKAYA \& MOSKVIN, 1959).

\section{CONCLUSION}

The studied materials allow the following conclusions to be drawn:

- The main part of the Late Cretaceous sea urchins of the Caucasus were geographically widespread and a Central European appearance;

- There was no climatic barrier during the Late Cretaceous between the Boreal seas and Neotethys allowing for the relatively free migration of sea urchin faunas from Central Europe towards the south-east, to the southern edge of the European palaeozoogeographic region.

\section{REFERENCES}

ALI-ZADE, A.A(1972): Cretaceous Belemnites of Azerbaijan [Melovye belemnity Azerbaidzhana - in Russian].- Moscow, Nedra, 280 p.

CESSA, F. \& WESTERMANN, G.E.G. (2003): Towards a guide to palaeobiogeographic classification.- Palaeogeography, Palaeoclimatology, Palaeoecology, 201/1$2,179-181$

DZABAROV, G.N. (1964): Upper Cretaceous Sea Urchins of Central Kopet Dagh and Their Stratigraphical Significance [Verkhnemelovye morskie ezhi Tsentral'nogo Kopetdaga i ikh stratigraficheskoe znachenie - in Russian].- Ashkhabad, Turkmenstan, Turkmenizdat, $164 \mathrm{p}$.

GAMBASHIDZE, R.A. (1967): Some molluscs and echinoderms from the Upper Cretaceous deposits of Georgia [Nekotorye mollyuski i iglokozhye iz verchnemelovych otlozheniy Gruzii - in Russian].- Georgia, Tbilisi, Works of the Institute of Geology of the Academy of Science of the Georgian SSR, Issue 15, 13-19.
GONGADZE, G.S. (1979): The Upper Cretaceous Echiniods of Georgia and their stratigraphic value [Pozdnemelovye echinoidei Gruzii i ichstratigraficheskoe znachenie - in Russian].- Tbilisi, Tbilisi St. Univ., 218 p.

HAUG, E. (1908-1911): Traité de Géologie. Les Périodes géologiques.- Paris, France, Armand Colin, 2, 539-2024.

KHALILOV, A.G. \& MELIKOV, O.G. (1988): Sea Urchins. [In Melovaya fauna Azerbajdzhana - in Russian].- In: ALI-ZADE, A.A. (eds.). Baku, Azerbaijan, Elm, 184-213.

MAKRIDIN, V.P. \& KATZ, Y.I. (1966): Some Technique Questions of Palaeozoogeographic Studies.- In: SOKOLOV, B.S. (eds.): Organizm and Environment in the Geological Past [Organism i sreda v geologicheskom proshlom - in Russian].Moscow, Russia, Nauka, 98-115.

MAKRIDIN, V.P. (1973): Principles for Recognition and Nomenclature of Divisions of the Palaeozoogeographic Zonation of Marine Basins [Prinsipy vydeleniya i nomenklatura podrazdelenij palaeozoogeograficheskogo rayonirovaniya morskich bassejnov - in Russian].- Palaeontol. Zh., 2, 3-9.

MAKRIDIN, V.P. (1982): Palaeobiogeography, its main directions and problems.- Geology on the Balkan Peninsula, 46, 211-224.

MAKRIDIN, V.P. (1983): Basic directions and problems of Palaeobiogeography [Iskopayemaya fauna i flora Ukrainy - in Russian].- In: SOKOLOV, B.S. (eds.): Materials of the third session of the Ukrainian Palaeontol Soc. Kiev, Ukraina, 97-103.

MAMEDALIZADE, A.M. (2005): To the stratigraphy of the deposits of the Upper Cretaceous in the vicinity of the village of Bory [K stratigrafii otlozhenij verchnego mela v okrecnostyach sel. Bory - in Russian].- Proceedings of National Academy of Science of Azerbaijan, 2, 58-61.

MAMEDALIZADE, A.M. (2011): Palaeozoogeographic Zonation of the Campanian and Maastrichtian Marine Basins of the Caucasus and Transcaspian.- Palaeontologich. Journ., 45/2, 154-158.

MELIKOV, O.G. (2002): The stratigraphical significance of echinoderms of the Lesser Caucasus [Stratigraficheskoe znachenie iglokozhich Malogo Kavkaza (Azerbaijan) - in Russian].- Baku, Azerbaijan, Nafta-Press, 99 p.

MELIKOV, O.G. (2005): Echinoderms of the Mesozoic- Cenozoic deposits of the Lesser Caucasus and their stratigraphycal significance [Iglokozhye Mezozoy-Kaynozoyskich otlozheniy Malogo Kavkaza i ich stratigraficheskoe znachenie - in Russian].Abstract of the doctoral dissertation. Baku, Azerbaijan, Nafta-Press, 53 p.

MOSKVIN, M.M. et al. (1949). Echinoidea [In Atlas rukovodyashchie formy iskopaemykh faun SSSR, Nizhniy Mel].- Moscow, Gosgeoltekhizdat, 9, 98-130.

MOSKVIN, M.M. (1986): Regional stratigraphical essays: Lesser Caucasus. Stratigraphy of the USSR: Cretaceous system.-In - SOKOLOV, B.S. (eds.). [Regional'nye stratigraficheskye ocherki: Malij Kavkaz. Stratigrafia SSSR: Melovaya sistema]. Moskow, Nedra, semi vol. 1, 238-251.

NAIDIN, D.P. (1964): Upper Cretaceous belemnites of the Russian platform and adjacent areas: Actinocamacs, gonioteuthis and belemnocamacs [Pozdnemelovye belemnity Russkoj platformy $i$ sopredel'nych oblastej: Actinocamacsy, goniotejtisy $i$ belemnocamacsy - in Russian].- Moskow, Mosk. St. Univ. Publ. House, 190 p.

POSLAVSKAYA, N.A. \& MOSKVIN, M.M. (1959): Echinoderms.- In: MOSKVIN, M.M. (eds.): In Atlas of the Upper Cretaceous Fauna of the Northern Caucasus and Crimea [Verkhnemelovoi fauny Severnogo Kavkaza i Kryma]. Moscow, Gos. Nauchno-Tekhn. Izd. Neft. Gorno- Topl. Lit., 237-304.

RENGARTEN, V.P. (1959): Stratigraphy of the Cretaceous deposits of the Lesser Caucasus. Regional Stratigraphy of the USSR. [Regional'naya stratygrafiya SSSR].Moskov, Publishing House of the USSR Academy Science, $540 \mathrm{p}$.

SAVCHINSKAYA, O.V. (1974): Echinoidea-sea urchins.-In: KRIMHOLTS, E.Y. (eds.): [Echinoidea- morskiye ezhi, in Atlas verchnemelovoy faun Donbassa].- Moscow, Nedra, 303-333.

SAVCHINSKAYA, O.V. (1982): Conditions of the Late Cretaceous fauna of the Donetsk basin [Usloviya sushchestvovaniya pozdnemelovoj fauny Donetskogo basseina].Moskow, Nauka, $132 \mathrm{p}$.

SMITH, A.B. \& KROH, A. (editor) (2011): The Echinoid Directory. World Wide Web electronic publication. http://www.nhm.ac.uk/research-curation/projects/echinoiddirectory

TSAGARELI, A.L. (1954): Upper Cretaceous of Georgia [Verchniy mel Gruzii].- Publishing House of the Academy of Science of the Georgian SSR, Tbilisi, $540 \mathrm{p}$.

WESTERMANN, G.E.G. (2000): Biochore classification and nomenclature in palaeobiogeography: an attempt at order-- Palaeogeography, Palaeoclimatology, Palaeoecology, 158/1-2, 1-13. doi: 10.1016/S0031-0182(99)00162-5 